\title{
Up or down with the ecology cycle? Strategies for temporally rational ecological governance
}

\section{Political terms and ecological cycles}

Next budget and next election; dominant time spans in politics From the early nineteenth century onwards, the dominant political view of time was one of continuous 'progress' with the state at the centre of change (Ekengren 1998:30). This linear conception of time is, however, just one possible view. Political time can also be seen as (series of) distinct events or as connected points that have special meaning or importance. One can furthermore view political time as cyclical, with events recurring in a predictable fashion. The budgetary process is a prime example. Governments set strict timetables that bind the procedure step by step, and the organisation level by level, in a predetermined, annually repeated cycle (see Brunsson 1995:12 ff., 182 f.).

Elections are crucial political events reoccurring at predetermined intervals. They determine the views and uses of time among political representatives. Elected representatives then have two to five years before they face the verdict of the electorate at the next election. A major motivation for their actions and standpoints thus is how these influence the chances to become re-elected. Consequently, the immediate questions of here and now tend to take precedence over longer-term issues. The timing of a political initiative is often a strategic consideration by politicians bent on political gains (Edelman 1988). In combination with the constant pressure from the media, such strategic considerations may lead to extremely short term political horizons.

There are, however, also other conceptions of political time. 
Efforts are made to break the one-year cycle of the budgetary process by introducing three- to four-year budget cycles for certain policy fields. Perspectives of up to 15 years have been used in infrastructure planning and development. Defence policy works with 30- to 40-year perspectives when deciding on major air or naval systems of warfare. Politicians thus face a multitemporal situation, where they take part in an increasing number of interactions with different social and political time scales (Ekengren 1998:26).

Still, time perceptions in politics are predominantly geared towards the 'next budget' and the 'next election'. These cycles and predetermined points in time converge to instil into political and administrative life a bias in favour of the immediate scheduled tasks, and the wishes and reactions of the present electorate. The dramatic growth of information and communication technology enhances further this predominance for the 'here' and 'now' at the expense of the historic and well as future 'then'. Rapid and dramatic moves in global financial markets can - so is the lesson driven home by the 1992 economic turmoil in Sweden - put pressure on politicians to provide decisions literally 'within the hour' to avert a major national crisis.

\section{Doing time on earth; politics as ultimately fenced by natural ecocycles}

This institutionalised political shortsightedness is increasingly challenged. The long-term trends of population growth, water and air pollution, and possibly irrevocable climate change, have created doubts about the sustainability and productivity of the planet's ecosystems. The picture of 'Spaceship Earth' as a finite entity with finite resources has driven home the lesson, sometimes forgotten in the era of linear 'progress', that man - also political man - is ultimately fenced within nature and the productivity of its ecosystems. Nobody can escape from doing his or her time here. Furthermore, this recognition draws attention to the generational cycles of reproduction. If we are fenced in now, so will be our descendants, one generation after the other.

The emphasis on lifecycles and their importance for long-term productivity show that natural time can be seen as a circular phenomenon. Water circulates between the ground and the atmosphere. Plants and species come to life, mature, reproduce 
and die. A smooth and balanced functioning of the seasonal and other short-term patterns is the necessary basis for the systems' longer-term health and productivity. Just like politics, the natural environment thus exhibits a plurality of times, reaching from millennial geological changes to seasonal and even shorter cycles (see Adam 1994).

There is, however, an important difference between political cycles and ecological lifecycles. Short-term tactics and strategic timing may lead to a smoother functioning of the political processes of the day, but may detract from the longer-term viability and productivity of the political system as a whole by diminishing popular support and democratic legitimacy. While it may take only one line in a budget or bill to save a government coalition, that single line may devastate an ecosystem to the extent that it will take decades to restore it.

In the broadest sense then, political time is ultimately bound by the life cycles of ecosystems that produce and reproduce resources necessary for human life. Political actors can not escape from this basic relationship when they mobilise resources for collective endeavours by way of their democratically legitimated use of power in society. They are forced to find ways to achieve temporally rational ecological governance. Above all, they have to adopt an inter-generational time horizon. Present actions should be judged in the light of long-term ecological sustainability as well as autonomy for future generations.

\section{From here to sustainability; ways of reconciling political and ecological time scales}

There are several alternative ways of reconciling political and ecological time cycles. The most long-term binding perspectives have historically been found in physical planning, i.e., the process of directing, restricting, or even forbidding certain uses of land and resources. Planning regulations and processes infringe on present resource use to an extent that makes it perhaps the most authoritative way of reconciling political and ecological time perspectives. To pass the autonomy test, systems of comprehensive planning in ecological governance should thus exhibit participatory mechanisms that allow present stakeholders and the general public a meaningful say in the process before binding decisions are taken. 
Another alternative is to adapt more fully to the circular processes in nature by closing as much as possible the flows of goods, materials, energy and resources through society. Such ecocycle adaptation is fully achieved when 'the handling of the flows of material and other resources, like land, is such that natural ecocycles can absorb rest products and renew the resources for future generations, and does so with preserved biodiversity' (Ecocycle Commission 1997:16 f.). While leaving much room for autonomous choice to present generations, eco-cycle adaptation may create a temporal illusion if it does not fully achieve this ideal. Leaks and loopholes in the cycle, huge inputs of energy needed to redirect flows of goods and materials through society, as well as new uses for the energy and materials saved, all detract from sustainability (see Jänicke et al. 1999:128).

The strategy of increased resource use efficiency is actually directed towards 'beating time' by decreasing the input of resources to provide the same or a larger output of goods and services. This would make possible the transfer to the next generation of a sustainable society with leeway for autonomous choice without sacrificing present welfare. Linked to this strategy is a specific view of the relationship between economic growth, social welfare, and ecological sustainability, viz. ecological modernisation. At its core is the view that building a sustainable society demands new, resource-saving and resource-efficient technologies, which provide a rapidly growing market and thus become an engine for growth and jobs (see Gouldson and Murphy 1997:74 f.). Ecological modernisation is said to dissolve the perceived conflict between economic growth and environmental protection (Cohen 1998:150). Environmental protection and economic growth are turned into a positive-sum game, where industry finds anticipatory development of green technology profitable, and politicians can preach 'green' growth (Hajer 1995:26 ff., 273).

This shift in outlook is accompanied by changes in policy principles, instruments and organisation. The emphasis is on early internalisation of ecological values and modes of thinking among all relevant actors. Stable and foreseeable regulations, and increased use of economic and monitoring instruments, are expected to provide a good climate for innovative eco-technology. This in turn increases resource and energy efficiency in the processes of production, consumption and recycling, and may give 
forerunners comparative advantages in world markets (Stavins and Whitehead 1997:112; see Dobers 1997:63 ff., 114 ff.).

With the possible exception of planning, these strategies imply enormous problems of co-ordination and overview. The timing of actions and events becomes increasingly important, as does the question of what stage in the process of political and ecological reconciliation is actually reached. The 'New Public Management' focuses on goals and objectives as the most important aspect of managing large systems, leaving those responsible for implementation to decide on the most effective mix of instruments to attain these objectives. But might not this become an exercise in symbolic politics? For management by objectives to actually take on a self-binding character is crucially dependent on how the relationships between political orderers of action and administrative and other performers of action are institutionalised and organised. Management by objectives consciously brings relevant actors into the system of governance, in particular those contributing to the non-sustainable patterns of environmental and resource use. The translation of sustainability objectives to targets and action plans takes place at lower levels and in co-operation with affected interests and stakeholders (Jänicke et al. 1999:111). Much effort is put into setting up specific timetables for goal achievement. Comprehensive systems of monitoring in the form of commonly accepted indicators and operationalised measures are included. Together with specified target dates, this is meant to enable actors in the system to get commonly understandable answers when 'checking time', i.e., assessing progress (see Jänicke et al. 1999:68 ff.).

\section{Green and just in time; criteria for temporally rational ecological governance}

The precautionary principle urges decision-makers at all levels to take into account the future environmental and resource consequences of present action. But what is irreversible is uncertain, and might not be distinguishable until way into the future. To play it safe, decision-makers are thus pushed towards constraining present action beyond critical thresholds (see Barry 1999:225 f.). The institutional and procedural design is thus of utmost importance to safeguard against both ecological irreversibility and inter-generational injustice. 
When analysing the Swedish strategies to achieve temporally rational governance, we first look for specified target dates for achieving objectives of sustainable development. Ecological governance is temporally rational when these time schedules are based on, or linked to, ecologically relevant characteristics, such as 'safe' levels or concentration of substances, lifecycles relevant to the health of ecosystems, as well as to the scope and pace of resource and materials flows through society and the economy.

However, targets and dates do not become binding on the present if they are not accompanied by a well-developed system of surveillance and monitoring, as well as statistical measures and indicators. We thus look for premeditated ways of monitoring and evaluating goal achievement. Temporally rational ecological governance distributes specific responsibility for achieving certain targets to specific units, thus binding their future activities to the overarching objective of sustainable development. These instruments do not only show the state of progress. They also show which processes and activities in society put pressure on environment and resources, and the results of measures taken to counter such pressures.

Such an environmental and resource information system provides not only experts and administrators with opportunities to make autonomous judgements over time about the progress towards sustainability. A transparent process of decision-making, implementation and feedback also makes this possible for the ordinary citizen. Temporally rational ecological governance is thus democratic. The participants in the process to reach decisions on objectives, binding target dates, and methods of goal achievement are defined on the grounds of their contribution to, as well as dependence on eco-cycles, energy and material flows. Specific mechanisms are built in to safeguard the value of autonomy for future generations.

\section{The 'telescopic state' - binding the present for the future}

\section{Land use planning and restrictions on future resource use}

The conditions for land use and resource utilisation can be manipulated through the structuring of physical space (Eckhoff 1983:29). Ever since the dawn of the twentieth century, 'allocation of special functions to areas' (Glasbergen 1992:197) has been 
used in Sweden to set aside geographical areas as national parks, nature reserves, and nature conservation areas. By 1998, such areas reserved for future generations comprised over 38,000 square kilometres, equivalent to over eight (8) per cent of Sweden's total area (Statistics Sweden 2000:227 ff.). The 1968 Sarek Agreement, later ratified by Parliament, declared four major rivers in northern Sweden off limits for hydroelectric power exploitation. This binding decision was further confirmed in 1993, when the four rivers were labelled 'national rivers' (Cabinet Bill 1997/98:45, Part 1, p. 241).

The Planning and Building Act of 1947 made Sweden's local governments and their Building Committees responsible for all local planning. Geared towards housing and urban infrastructure, municipal master plans and detail plans provided general and specific guidelines for expected municipal expansion. Plans were made legally binding through ratification by Regional Administration Boards or, for larger and more important plans, by the national government (Lundqvist 1972, passim). The planning process did little to link local development to the scale and quality of natural resources. Increasingly frequent clashes among competitive demands for land and natural resources could not be resolved, and resource issues spanning many municipalities and whole regions were not properly addressed.

This led the national government to develop more comprehensive national physical planning. Surveys were made in the late 1960s of foreseeable demands for natural resources over the next 30 years for industrial production, urban development, outdoor recreation, and environmental quality. To this was linked an inventory of the location and amount of available resources. Areas where future clashes of interest might occur were then pointed out. Following simulations of alternative land use patterns, principles were established for an adequate location of different resource demanding activities. The system of National Physical Planning decided by Parliament in 1972 contained four elements:

- Guidelines for the planning of activities involving competing claims on land and natural resources.

- Guidelines for the planning of geographical areas with particularly intensive competition for land and natural resources. 
- Processes for implementing these guidelines into a national physical plan covering all of Sweden.

- Binding provisions for cases of severe conflicts over resource use implying comprehensive cross-sectoral impacts.

Decisions on the location of nine types of industrial and other activities with heavy demands and impacts on Sweden's natural resources and energy supply now had to be made by the Cabinet. The Cabinet's decision would then bind subsequent planning and environmental assessments. Environmental permit authorities could not prohibit an activity allowed by the Cabinet and vice versa. A municipal veto meant that the Cabinet could grant a location permit to a large-scale, resource-demanding activity only if the Municipal Board of Councillors in question had approved of such a location (Lundqvist 1979:248 f.).

Only a decade later, a Governmental Commission reported that Sweden's land use and resource planning was not sufficiently geared towards long-term sustainable development. Planning for use and protection of natural resources should be guided by such concepts as the carrying capacity of ecosystems and biochemical cycles. In particular, the use of non-renewable resources should be put under much more stringent control (SOU 1983:56). However, to make sustainability the core criterion in land use and resource planning was an idea whose time had yet to come. A 1984 Cabinet memorandum pronounced it more 'reasonable' to proceed from the present National Physical Planning programme. The 1985/86 Cabinet proposal for a new Natural Resources Act explicitly stated that the resource management concept should have a relatively narrow content, linked to the use of man's physical environment (see SOU 1993:27, p. 280 f.).

However, some steps to incorporate emerging ideas on longerterm sustainable development were taken in the 1987 Natural Resources Act (NRA). This Act was an umbrella, covering and 'guiding' eight other acts relevant to natural resource use, among others the Planning and Building Act, also codified in 1987 (Cabinet Bill 1990/91:90, pp. 165 ff.; Michanek 1991:22 ff.). The NRA made Environmental Impact Statements (EIS) mandatory for all potentially harmful activities requiring a permit under any of these acts. The EIS requirement included location of large projects and facilities, environmental permit procedures, large-scale 
use of water and forest resources, as well as infrastructure developments (see Cabinet Bill 1990/91:90, pp. 169 ff.).

The Natural Resources Act and the acts covered by it are now incorporated under the comprehensive Environmental Code ratified in 1998. The inclusion of the NRA in the Environmental Code was seen as an instrument for comprehensive judgements in the planning process to secure 'an ecologically, socially, culturally and socio-economically sound resource management'. The Code enumerates those areas and natural resources in Sweden that are of 'national interest'. Such areas may be subject to industrial or other polluting activities only under very special circumstances. Further areas of 'national interest' can be designated through a process involving national agencies and Regional Administrations. However, these areas become fully accepted as of 'national interest', and thus binding on future activities, only after an explicit decision under any of the relevant acts within the NRA/EC umbrella (Cabinet Bill 1997/98:45, Part 1, pp. 242 ff.).

Under present (2003) planning legislation, municipalities establish an overview plan for their territory, describing future land and water use, and defining areas for infrastructure, commercial and housing developments. Overview plans are not binding; only the detail plans for particular areas are. Municipalities may issue area regulations for areas outside detail plans. Before the Municipal Board adopts an overview plan, the Regional Administration must issue a report asserting whether or not the plan is compatible with the NRA/EC definition of areas of 'national interests' (Michanek 1991:28 ff.; Cabinet Bill 1994/94:230).

Indeed, the 289 municipalities are issued a tall order to save areas for the future. By the turn of the century, the more than 2,200 areas declared of 'national interest' covered nearly 25 per cent of Sweden's total area (Statistics Sweden 2000:229). About one-quarter of these areas are physically protected as nature reserves, which means that industrial activities cannot be located there. The other 75 per cent may be secured for the future through municipal prohibitions, environmental permit decisions, or Regional Administrations' conditions for exploitation (Sveriges Nationalatlas 1991:164 ff.). 
Planning for the present, the future, or ...?

What then, does this planning process offer in terms of sustainability and autonomy? First of all, it is reiterative; local governments are expected to renew the overview plans by fiveyear intervals. In reality, however, the time perspective is often shorter. Plans are 'rolling', and quite often subject to negotiations between local governments and parties with relatively short-term interests in resource exploitation and commercial development. The National Audit Office contended in 1996 that the Swedish process of environmental impact assessment (EIA) exhibited several flaws. Environmental expert authorities had no regulated standing in the process. Long-term environmental effects went unattended, due to lack of necessary competence for the review of EIA documents. Usually, the alternative preferred by the exploiters was the only one being assessed in the process. All in all, Swedish EIA process was said to lack formal rules, standards of content, and allocation of rights and duties among actors (National Audit Office 1996: passim; see Kjellerup 1997).

Criticism also concerned the democratic aspect of planning. Formally, municipalities are required to arrange procedures of consultation and hearings with the citizens, firms, organisations and others concerned when they prepare detail plans. Changes in 1994 actually aimed at strengthening citizen participation (Michanek 1991:28 ff.; Cabinet Bill 1994/94:230). However, the National Audit Office concluded in 1996 that public involvement comes in too late, if at all (National Audit Office 1996: passim; see Kjellerup 1997).

The 1997/98 Cabinet Bill on National Environmental Objectives put much emphasis on the idea of A Sustainable Sweden. A broad conception of sustainable development is used. The Cabinet stated that the 15 long-term NEOs (see further below, pp. 65-7) should guide all physical planning. 'Through cooperation across sectoral lines, national and municipal authorities shall promote an ecologically sustainable development with a good living environment for all' (Cabinet Bill 1997/98:145, p. 321 ff.). New instruments were conceived. Regional environmental and resource management (ERM) programmes are to be developed for areas with such severe environmental and resource management problems that environmental quality norms may be imposed. These programmes are to be based on the NEOs, on the 
'national interests' determined on the basis of NRA/EC regulations, as well as on the regional environmental strategies (STRAMs) worked out by the Regional Administrations (see Arwidsson 1999:8 f.).

Planning is expected to integrate the precautionary principle through the EIA process. The government claims that Swedish EIAs reflect the integration of environmental concerns in a proactive planning process. However, there is an integration confusion' between a consensual planning process and an adversarial examination at one stage in that process. There is no screening of alternatives, no scoping of effects of interrelated decisions, no early public consultation, no requirements for non-technical summaries, and no formal EIA decision. Long-term binding effects of contextual decisions may thus still go unattended (Emmelin 1998:189, 205). The building of the railroad tunnel through Hallandsas (to allow for a 12 minute gain in travel time between Gothenburg and Copenhagen) caused an ecological scandal affecting the sustainability of the region. It thus provides a glaring example of deficiencies in the planning process that detract from temporally rational ecological governance (SOU 1998:137, esp. pp. 91 ff., 123 f.).

\section{A silent revolution: self-binding for the future through 'management by objectives'}

An important distinction in the thinking on governance is between 'policy' and 'management'. As mentioned, 'New Public Management' points to management by objectives (MBO) as a flexible way of moving towards commonly formulated and shared views of a future state of affairs. As a temporal strategy of governance, $\mathrm{MBO}$ exhibits the following characteristics:

- Co-operative and consensual processes to formulate objectives, including (measurable) target levels and dates, and dominated by political decision-makers.

- Deliberate ways of internalising common problem views among implementers and target groups.

- Decentralised competence to use program resources for implementing common objectives, involving negotiation and agreements among programme administrators and (organised) target groups. 
- Continuous monitoring and assessment of progress in relation to target levels and dates, with a strong role for political decision-makers.

The MBO strategy thus leaves much discretion and responsibility to administrators in the process of instrumentation and implementation. However, continuous political evaluation and goal (re)formulation together with conscious methods for internalisation of objectives and problem views are thought to lead to expected future outcomes (see Jänicke et al. 1999:68 ff.). Evidently, the possibility that the MBO strategy will take on a self-binding character is very much dependent on how the relationships between the political principals (the orderers of action) and the agents (the performers of action) are institutionalised and organised into a coherent system of governance. Clear objectives with explicit time limits, linked to specific responsibilities and resources provided to specified actors, would certainly add to its 'binding' nature.

The Swedish process of reorienting traditional environmental policy towards one of sustainable development began in the mid 1990s. In the spring 1997 Budget Bill, the Cabinet proposed a broad strategy for sustainable development, to be based on three overarching objectives; protection of environmental quality, efficient use of resources, and sustainable ecosystem productivity (Cabinet Bill 1996/97:150). An earlier report of the National Agenda 21 Committee had pointed to the incoherence among the numerous 'goal like' expressions in official policy statements. In September 1997, the Environmental Protection Agency proposed that those more than 170 'goals' be condensed into 18 environmental quality objectives (SEPA 1997).

In May 1998 the Cabinet presented a bill proposing 15 'national environmental objectives' (NEOs) to be achieved 'within one generation', i.e., by 2020-25:

- Reduced Climate Impact

- Clean Air

- Natural Acidification Only

- A Non-Toxic Environment

- A Protective Ozone Layer

- A Safe Radiation Environment 
- Zero Eutrophication

- Flourishing Lakes and Streams

- Good-quality Groundwater

- A Balanced Marine Environment, Flourishing Coastal Areas and Archipelagos

- Thriving Wetlands

- Healthy Forests

- A Varied Agricultural Landscape

- A Magnificent Mountain Landscape

- A Good Built Environment

This was the starting point for 'a system of government by objectives and results' that - in the eyes of the Cabinet - presented the 'most effective way of governing a broadly conceived programme for sustainable development with participation from all sectors of society'. The NEOs would be broken down into further, more precise sectoral (and geographical) targets, to be decided upon by the Cabinet. Involved public agencies and municipalities would enjoy wide discretion in selecting instruments to achieve the goals, and voluntary action by firms and enterprises was welcomed (Cabinet Bill 1997/98:145, p. 38 f., esp. p. 41). The further content of the bill indicated that this new structure would not become another exercise in symbolic politics. It outlined a process for developing targets and action plans for different sectors, and distributed clear responsibilities for this process among agencies and authorities. Furthermore, the proposal envisaged a system of indicators and mechanisms for monitoring and surveying progress of the work towards the 15 objectives (Cabinet Bill 1997/98:145, pp. 169 ff.).

The MBO process for sustainable development started even before Parliament had voted on the NEO Bill. Already in June 1998, the Cabinet instructed 17 sectoral agencies and all the Regional Administrations to develop proposals for targets, sectoral goals and action plans necessary for reaching the NEOs within their area of competence and authority. The Swedish EPA was to provide co-ordination and support to sectoral agencies in their work on targets and action plans, and make sure all agencies reported back to the Cabinet by October 1999. The Cabinet furthermore appointed a Parliamentary Commission to review the agency reports and particularly evaluate the environmental, 
socio-economic, fiscal, and specific sectoral consequences of targets and action programmes. The Commission presented its final report to the Government in June 2000 (SOU 2000:52), and a Cabinet Bill was sent to Parliament in April 2001 (Cabinet Bill 2000/01:130).

The temporal perspective is evident and, to say the least, brave. The objective is 'to hand over to the next generation a society in which the major environmental problems have been solved' (italics added). The structure of this $\mathrm{MBO}$ system of ecological governance is as follows (Cabinet Bill 2000/01:130, pp. $11 \mathrm{ff}$.):

- The 15 NEOs define the state of environmental quality to be achieved by 2025; one main definition of each 'generational' objective is further developed into sometimes as many as ten specific features of the environmental quality to be achieved.

- Interim targets state the direction and time scale for ongoing, concrete measures; most interim targets relate to what should be achieved by 2010 in terms of emission level reductions or specified levels of environmental quality.

- Action strategies to co-ordinate measures to achieve several NEOs at the same time, as well as other policy objectives:

1. A strategy for more efficient energy use and transport

2. A strategy for non-toxic and resource-efficient cyclical systems, including an integrated product policy

3. A strategy for management of land, water and the built environment.

For each of these strategies, an orchestrated set of policy instruments is envisaged. The 'energy and transport' strategy builds, among other things, on a 'green' tax shift in the range of SEK 30 billion ( $€ 3.3$ billion) up to 2010 . The 'eco cycle' strategy envisages more 'green' tender and procurement in addition to an integrated product policy. Finally, the 'resource management' strategy rests on regulatory measures and procedural safeguards to strengthen protection of valuable nature and water resources, and a revision of the physical planning process (Cabinet Bill 2000/01:130, pp. 196 ff.).

Three modes of implementation are pointed out as crucial to the success of these strategies. One is the integration of responsibility for an ecologically sustainable development into the 
mandates of public agencies and the activities of enterprises and other organisations in various social sectors. As for the 24 public agencies specifically pointed out, this mandate includes identifying their 'ecological' roles, formulating action programmes with specified sectoral objectives and measures, assessing the effects of these measures on the public economy, and making sure that sectoral action programmes are implemented by making them part of all their decision-making. To ease this ecological administrative reform, public agencies are to make Environmental Management Systems (EMS) an integrated part of their processes. Another mode of implementation is to complement legal and economic instruments with voluntary agreements with industry and business. These agreements can be based on existing regulation, or form the basis for action instead of regulations. The argument for such agreements is that they may lead to more costefficient methods of achieving sustainable development (Cabinet Bill 2000/01:130, pp. 17 ff.).

The third mode is a comprehensive system of monitoring and evaluation, based on a system of statistics that comprises the state of the environment, reflects the development of factors affecting environmental quality, and points to measures needed to counter negative trends. This will include data from the National Environmental Surveillance Network, as well as statistics on the use, accumulation, recirculation and productivity of materials and energy in society. A system of indicators of sustainable development (gröna nyckeltal) is to be developed to furnish decision-makers and the general public with information on Sweden's progress towards sustainable development. An Environmental Objectives Board (EOB) was established under the SEPA in 2002 to co-ordinate the efforts of the national and regional authorities with specific sectoral responsibilities for sustainable development. The Council will report directly to the Cabinet to provide the basis for the Cabinet's annual report on progress towards achievement of NEOs. A more in-depth report on the progress towards 'Sustainable Sweden' is to be delivered to Parliament every four years (Cabinet Bill 2000/01:130, pp. 223 ff.).

If this $\mathrm{MBO}$ process continues according to plan, Sweden will in a few years have a coherent plan of national, sectoral, and regional action, complete with time-tables for achievement of 
sustainable development. Sweden will also have a system for continuous review and measurement of trends and developments indicating whether and to what extent achievement of the national environmental goals and interim targets is actually forthcoming. This gives an impression of Swedish environmental and resource management as an example of democratic self-binding. The formal procedure of ratifying objectives through parliamentary vote fulfils the democratic criterion. There is an easily understood temporal goal; an environmentally sound society is to be achieved 'within one generation'. The elaboration of interim targets and operationalisation of sectoral goals means that agencies become bound to programmes and time-tables they have helped design and have come to internalise as 'feasible' to themselves as well as to affected sectoral actors and interests along the way. The democratic self-binding is further strengthened by the elaborate system of monitoring and evaluation. Built as it is on extensive statistics and understandable indicators, it enables the general public to make autonomous judgements about progress towards sustainability, and thus to hold political and administrative decision-makers accountable for the success or failure of the MBO strategy.

\section{Towards the 'ecocycle society'? Closing the loops of goods and materials}

Ecocycle adaptation; policy action from the 1992 Recycling Bill to the present

The Bourgeois Government labelled its Ecocycle Bill of 1993 as a first step towards 'a society based on the principle of ecocycles' (Ministry of the Environment 1993:3). The bill introduced specific demands and targets to reduce solid waste and adapt products for reuse and recycling. Demands were defined as specific percentages to be reached by 1997 for reuse or recycling of packaging materials that were already then recycled to a large extent (SFS 1994:1235). Targets concerned packaging materials that were only recycled by small factions of the total volume (Cabinet Bill 1992/93:180, p. 78 f.). The Government introduced the principle of producer liability, comprising the whole life cycle of the package or material, and including responsibility to take care of the waste in an 'environmentally acceptable' way (Cabinet 
Bill 1992/93:180, pp. 53 ff.). A special Ecocycle Commission was appointed in 1993 to 'develop a strategy for eco-cycle adaptation of the commodities sector and propose successive extensions of the producer liability' (Ecocycle Commission 1997:3).

Apart from some general remarks on the necessity for adequate separation and collection systems, and of the need to inform consumers, the 1993 Cabinet Bill left the manufacturers to decide on the 'how' of this eco-cycle adaptation. The largest manufacturers in branches affected by the liability regulations swiftly formed a self-regulatory organisation. Special 'materials companies' were established for cardboard, corrugated paper, plastics and metals, as well as a special recycling company for glass. These companies are run as 'not-for-profit companies', contracting out the actual collection and recycling. The materials companies control the reuse and recycling activities of their member producers, while producers outside the companies account for their reuse and recycling to the SEPA (Statistics Sweden 2000:114). Combined, they form the service organisation that disseminates information on collection and recycling, and how and where to deposit packaging (www.repa.se).

What have been the Government's activities after the 1993 Bill? A 1996 bill passed by Parliament mandated the Cabinet to prohibit the dumping of burnable and organic waste by 2002 and 2005, respectively (Cabinet Bill 1996/97:172). The 1997 strategy report from the Ecocycle Commission suggested quite ambitious objectives for infrastructural change, adaptation of new goods and commodities, and waste products (Ecocycle Commission 1997:28). The 1998 Bill on National Environmental Objectives extended the list of goods and commodities subject to producer liability, and linked this to target levels and dates. Up to 80 per cent of worn out tyres were to be recycled or taken care of in an environmentally friendly way by manufacturers and dealers after 1998. Car manufacturers must take care of cars registered 1997 and later left for scrapping after 1998, and to make 85 per cent of each individual post-1997 model car recyclable or reusable by 2002. This share is to reach 95 per cent by 2015. For electric and electronic products, regulatory changes concerning the producer liability were put on the books (Cabinet Bill 1997/98:145, pp. $201 \mathrm{ff}$.)

The 1998 bill also addressed the eco-cycle adaptation of large- 
scale systems in the society's infrastructure, such as waste dumping and water and sewage. The prohibitions against dumping burnable and organic waste by 2002 and 2005, the pending permit regulations for waste transportation, and the pending proposal to introduce a tax on all dumped waste would, in the Cabinet's view, increase the assortment of waste at the source and its use for recycling or energy production. The objective was to reduce, by 2005 , the total volume of dumped waste by 50 to 70 per cent in relation to 1995 volumes (Cabinet Bill 1997/98:145, p. 146, 205 f.). As for the closing of nutrient cycles between urban and rural areas, the 2005 prohibition against dumping of organic waste would also concern sludge from sewage treatment plants (Cabinet Bill 1997/98:145, p. 207 f.).

A Cabinet Communication to Parliament in May 2000 reported on a strategy for a sustainable products policy. Working closely with the EU, and adopting a life-cycle perspective, the Swedish Government and its agencies will continue to work towards decreasing the negative impact on human health and the environment of commercial products. Measures comprise information, EMAS, green tender and procurement, green labelling and standardisation, as well as widened producer liability (Cabinet Communication 1999/2000:114, passim). Elaborating on the strategy for non-toxic and resource-efficient cyclical systems in its NEO bill of 2001, the Cabinet pointed to several new initiatives that are to be taken on issues such as an environmentally adapted products policy, international co-ordination, a programme for the production, use and retrieval of chemicals, reduction of the dumping of waste, and others (Cabinet Bill 2000/01:130, pp. 209 ff.). A special Commission was set up to report during 2001 on further concrete measures to extend producer liability to other product areas (Dir. 2000:28).

Ecocycle adaptation in practice; leaks, loopholes, and full circles How far, then, have Sweden's efforts towards eco-cycle adaptation progressed in practice? Five years after the producer liability regulations came into force, annual recycling had increased by 130,000 tons for packaging materials, by 10,000 tons for paper, and by 10,000 tons for tyres. Of the 20,000 companies and firms affected by producer liability for packaging materials, producers accountable for 90 per cent of all packaging materials in Sweden 
had joined the materials company in question (http://environ.se as of June 15, 1999).

As shown in Table 3.1., there are several examples of relative 'success' in the Swedish process. The most obvious closing of life cycles concerns products that actively involve consumers. Glass and PET bottles, and aluminium cans, are reused and recycled to the extent that targets are already reached. So is the case for recycling of paper from newspapers and journals. A contributing factor to this achievement is most probably that price conscious consumers make use of the system of repayment for old bottles and cans in force at grocery stores throughout the country. Furthermore, local governments have arranged recycling stations in most neighbourhoods, where individuals and households can deliver paper, cardboard, bottles and cans, as well as batteries and old clothes. It is also notable that several of the targets for more 'industrial' recycling and reuse are close to being reached.

However, these examples of relative success in closing cycles of goods and materials comprise only those areas subjected to producer liability. A system for collection, transport and reuse by manufacturers can be built up by reversing the flows from consumers to producers. A spring 1998 survey of nine industrial branches showed that car manufacturers, producers of electric and electronic products, tyre companies and the packaging industry all use several ecocycle adaptation criteria throughout the production phase. However, only a few areas report on prolonged product life cycles. Even fewer engage in making their products upgradeable (Ecocycle Commission 1998: 165 ff.). Far greater challenges to eco-cycle adaptation are raised by the large-scale systems in the society's infrastructure. With lifecycles of up to 150 years, most were built up long before the (re)discovery of the problems of the commons. The effect is a locking in of flows of nutrients, energy, materials, and waste in technologies and structures (Ecocycle Commission 1997, ch. 7).

In terms of sustainability, the strategy of eco-cycle adaptation thus still has a long way to go. The 'direct material input' (DMI) into the Swedish economy was close to 25 tons per capita in 1998. Input of fossil fuels seems to have stabilised during the 1990s, while that from other non-renewable materials oscillates. There is, however, a steady increase in the input of renewable resources. About 10 per cent of the DMI becomes waste, and half 
Table 3.1 Demanded and estimated actual levels of recycling and reuse for different goods and commodities subjected to producer liability in Sweden.

\begin{tabular}{|c|c|c|c|}
\hline \multirow{2}{*}{$\begin{array}{l}\text { Good or } \\
\text { commodity } \\
\text { Packages }\end{array}$} & \multicolumn{2}{|c|}{$\begin{array}{l}\text { Demanded level of recycling or reuse, } \\
\text { and year of attainment }\end{array}$} & \multirow{2}{*}{$\begin{array}{l}\text { Actually } \\
\text { attained levels } \\
1999 \text { in \% } \\
\end{array}$} \\
\hline & Up to June 2001 & After June 2001 & \\
\hline Glass containers & $\begin{array}{l}70 \% \text { recycling or } \\
\text { reuse of material }\end{array}$ & $70 \%$ recycling & 84 \\
\hline $\begin{array}{l}\text { Corrugated } \\
\text { cardboard }\end{array}$ & $\begin{array}{l}65 \% \text { recycling or } \\
\text { reuse of material }\end{array}$ & $65 \%$ recycling & 84 \\
\hline $\begin{array}{l}\text { Cardboard, } \\
\text { cartons }\end{array}$ & $\begin{array}{l}30 \% \text { recycling or } \\
\text { reuse of material }\end{array}$ & $\begin{array}{l}70 \% \text { ( } 40 \% \text { reuse } \\
\text { of material) }\end{array}$ & 40 \\
\hline Steel sheets & $\begin{array}{l}50 \% \text { recycling or } \\
\text { reuse of material }\end{array}$ & $70 \%$ recycling & 62 \\
\hline $\begin{array}{l}\text { Aluminium, } \\
\text { (except beverage } \\
\text { containers) }\end{array}$ & $\begin{array}{l}50 \% \text { recycling or } \\
\text { reuse of material }\end{array}$ & $\begin{array}{c}70 \% \text { ( } 40 \% \text { reuse } \\
\text { of material) }\end{array}$ & 33 \\
\hline $\begin{array}{l}\text { Aluminium, } \\
\text { beverage containers }\end{array}$ & $90 \%$ recycling & $\begin{array}{l}90 \% \text { reuse of } \\
\text { material }\end{array}$ & 84 \\
\hline $\begin{array}{l}\text { Plastics (not } \\
\text { PET bottles) }\end{array}$ & $\begin{array}{l}30 \% \text { recycling or } \\
\text { reuse of material }\end{array}$ & $\begin{array}{l}70 \%(30 \% \text { reuse } \\
\text { of material) }\end{array}$ & 34 \\
\hline Wooden packages & & $\begin{array}{l}70 \% \text { ( } 15 \% \text { reuse } \\
\text { of material) }\end{array}$ & \\
\hline $\begin{array}{l}\text { Packages, other } \\
\text { material }\end{array}$ & & $\begin{array}{l}30 \% \text { ( } 15 \% \text { reuse } \\
\text { of material) }\end{array}$ & \\
\hline PET bottles & $\begin{array}{l}90 \% \text { recycling or } \\
\text { reuse of material }\end{array}$ & $\begin{array}{c}90 \% \text { reuse of } \\
\text { material }\end{array}$ & $\begin{array}{c}91 \text { (refill), } 73 \\
\text { (reuse of } \\
\text { material) }\end{array}$ \\
\hline $\begin{array}{l}\text { Returnable glass } \\
\text { bottles }\end{array}$ & $95 \%$ recycling & & 98 \\
\hline \multicolumn{4}{|l|}{ Other Products } \\
\hline Cars & & $\begin{array}{l}85 \% \text { reuse of } \\
\text { material (from } \\
2002 \text { ) }\end{array}$ & \\
\hline Tyres & \multicolumn{2}{|c|}{$80 \%$ reuse of material (from 1999 ) } & 92 \\
\hline $\begin{array}{l}\text { Newspapers and } \\
\text { recyclable paper }\end{array}$ & \multicolumn{2}{|l|}{$75 \%($ from 2000$)$} & 79 \\
\hline
\end{tabular}

Source: www.environ.se/index.php3?main=/dokument/teknik/avfall/avfall1.htm (as of September 2001) 
of this waste is recycled into the economy. It should also be noted that about 20 per cent of the annual DMI is hazardous to human health and the environment (Statistics Sweden 2000:108).

The eco-cycle adaptation strategy shows some interesting features in terms of autonomy. The Social Democratic government has stated that a 'Sustainable Sweden' should be achieved 'without disturbing effects on market competition', and as far as possible through voluntary action and negotiated solutions, also involving consumers (Cabinet Bill 1997/98:145, pp. 196 ff.). While providing consumers and citizens with incentives for 'good environmental conduct', the markets for recycling and reuse established in sectors subjected to producer liability, and the continuous information campaigns leave the choice of conduct to the individual. The implementation of the producer liability concept through branch agreements is seen as a model for the future widening of that concept.

\section{Changing gears - policies for resource efficiency}

Factor Ten and the quest for efficiency in energy and transport In its September 1997 report to the Parliament on 'Ecological Sustainability', the Social-Democratic Cabinet pointed to the need to make energy and material flows compatible with sustainable development. It would be necessary to achieve 'a manifold decrease in the demand for energy and materials'. The Cabinet explicitly pointed to the 'Factor Ten' concept, i.e., a tenfold effectivisation of resource use over the next two generations as 'a signal of the necessary level of effectivisation ... [and] ... a compass to stimulate new ideas' (Cabinet Communication 1997/98:13, p. 9). The Cabinet thus seemed to have accepted the thinking of its Ecocycle Commission: 'factor ten can be used as a benchmark for the need to dematerialise' production and consumption in a highly industrialised country like Sweden (Ecocycle Commission 1997:60).

Seven months earlier, in February 1997, the Social-Democratic Cabinet had reached an agreement with the Left Party and the Greens on a programme for 'sustainable' energy provision. In the March 1997 Energy Bill, the Cabinet stated that the exodus from the nuclear energy society agreed upon by the three parties opened up for a cost-effective energy provision with an emphasis 
on renewable energy sources, and with low future impacts on health, environment, and climate. Electric energy should be provided through a system of domestic, renewable and sustainable energy sources, and combined with efficient energy use and low use of fossil fuels. Not only would this ease the transformation into an ecologically sustainable society, but it would also stimulate Sweden's economic and social development. As much as SEK 8 billion would be allocated to support investments in already functioning energy-efficient technology and in renewable energy sources and to stimulate the development and use of competitive, efficient, environment-friendly energy technologies based on renewable sources (Cabinet Bill 1996/97:84, p. 28 f.).

The efficiency drive in the Energy Bill was clearly anchored within the Cabinet's by then emerging strategy of 'ecological modernisation' (see below, pp. 77-81). At the core of the arguments of the Minister of Industry and Trade was the traditional Social-Democratic view that increased production and economic growth is decisive for employment and thus welfare. A basic favourable element in this respect, argued the Minister, is the secure provision of inexpensive electric energy to industrial production. The new 'non-nuclear' energy policy built on the premise that industrial use of electric energy should be allowed to increase - but must also become more efficient - over the next decade (Cabinet Bill 1996/97:84, p. 7).

In the 2001 Cabinet Bill on National Environmental Objectives, the strategy for more efficient energy use and transportation is particularly tied in with the following NEOs: Clean Air, Reduced Climate Impact, Natural Acidification Only, No Eutrophication, and A Good Built Environment. The quite ambitious 2010 interim targets for these NEOs would seem to require very tough measures, impinging on individual autonomy. The Bill foresees an increased use of economic instruments to make the environmental costs explicit and to stimulate energy effectivisation and further development of performance standards for vehicles, machines and other moving equipment. Green tax reforms in the vicinity of SEK 30 billion were indicated for the period up to 2010, including increased $\mathrm{CO}_{2}$ and energy taxes. There will also be a programme for infrastructural changes to achieve a sustainable transportation system (Cabinet Bill 2000/01:130, pp. 198 ff.). 
What then are the implications for sustainability from recent patterns of efficiency and productivity in energy and transportation? Final energy use decreased in industry and the built environment in the latter half of the 1990s. Energy use per SEK of product value sank by one-third from 1980 to the end of the century. Energy productivity rose steadily by about $1 \frac{1 / 2}{2}$ per cent annually (SOU 2001:2, pp. $141 \mathrm{ff}$.). The pattern is not that positive for the transport sector. Final energy use rose steadily in the 1990s. The amount of gasoline per vehicle kilometre decreased by 12 per cent in the 1980 s, but has since levelled out. The shift in demand towards heavier vehicles, and the lower number of passengers per vehicle together contribute to higher use of gasoline per passenger kilometre in 1998 than in 1970 (SOU 2001:2, pp. $147 \mathrm{ff}$.$) .$

\section{Sweden and the middle way: seeking consensual ecological modernisation}

When the then Minister of Finance Göran Persson assumed leadership of the Swedish Social Democratic Party in March 1996, he surprised many observers by proclaiming the achievement of an 'ecologically sustainable society' as a new, 'noble mission' for his party. Presenting his Cabinet Policy Platform two weeks later, Prime Minister Persson stated that Sweden should be 'an internationally driving force and a forerunner in the endeavours to create an ecologically sustainable development' (Parliamentary Record, March 22, 1996). The temporal aspect was of central concern. The present pattern of continued economic growth would - so argued the Ministers and the party elite - overtax natural resources and leave future generations disinherited (Prime Minister Göran Persson 1997; Environmental Minister Anna Lindh 1997; DESD 1997:1; SAP 1997).

However, the transformation of the country into 'A Sustainable Sweden' should not mean draconian measures towards present generations. The ruling Swedish Social Democrats put a strong emphasis on the social and economic aspects of sustainable development. Allusions were made to the glorious past, when the party ruled over the transformation of Sweden into a modern welfare state, folkhemmet (the 'People's Home'; see Tilton 1990:125 ff.): 'Now, we have a similar mission. We will realise the vision of a green welfare state, and bring about 
a thorough ecological modernisation of Sweden' (SAP 1997; italics added). In its Finance Plan for 1997, the Social Democratic Cabinet stated that the transformation of Sweden into a 'green people's home'

means an increased demand for investments and development of modern technology. Energy is a case in point. If Sweden is a forerunner in developing new technology, new markets are created for Swedish business and many new firms will be established in the energy sector. (Cabinet Bill 1996/97:150, p. 22)

Said the Prime Minister: '[W]e will all gain from ... the marriage of ecology, economy and employment'. (Cabinet Policy Platform, September 17, 1996; Environmental Minister Anna Lindh 1997; DESD 1997:2; Prime Minister Göran Persson 1997; SAP 1997; see Edman 1998)

This policy shift indicated a wholesale acceptance of the strategy of ecological modernisation (see Jänicke 1985, Hajer 1995, Gouldson and Murphy 1997, Lundqvist 2000). This strategy is founded on a combination of regulatory and economic policy instruments to propel the growth of new, green technologies and production/consumption processes in society (see Murphy 2000:3). This way of promoting economic growth is in fact a long-term hallmark of Sweden's Social Democrats; it seemed only 'natural' to extend it to promote 'green' growth in consensus with broad socio-economic interests. Ministers pointed to the fact that Swedish public sector annually purchases goods and services for nearly 300 billion SEK (about $€ 33$ billion). The government could thus 'directly create a market' for green goods and services through an active 'green procurement' policy for public agencies at all levels. The tax system should be subjected to successive changes to promote both eco-sustainability and the competitiveness of Swedish firms and enterprises. Massive government support of eco-investment programmes would also be forthcoming to stimulate the ecological modernisation - read greening - of the 'People's Home' (Environmental Minister Anna Lindh 1997; Prime Minister Göran Persson 1997; SAP 1997).

The Delegation for Ecologically Sustainable Development (DESD) formed in January 1997 within the Cabinet became the vehicle for this strategy. The Delegation's first, explicitly shortterm assignment was to 'develop a platform for the Cabinet's 
comprehensive policy for an ecologically sustainable society.' (Parliamentary Record January 22, 1997, Prime Minister Göran Persson). The Delegation's March 1997 report on A Sustainable Sweden called for a Sustainability Investment Programme to run from 1998 to 2004. It included

- one billion SEK to eco-cycle adjustment of built environments and infrastructure;

- nine billion SEK to eco-cycle transformation of the Swedish energy system, and;

- six billion SEK to local investment programs (LIPs) for sustainability by municipal governments (DESD 1997).

Not only was such a programme important for the possibilities of future generations to lead a good life, argued the Delegation. The 'most thrilling aspect' of the work towards sustainable development was to 'be able to utilise the markets to open up for environmentally adapted products and services', thus stimulating growth and competitiveness, and creating new jobs. The Cabinet's spring 1997 Economic Bill allocated 12,6 billion SEK for the period 1998-2000 to the Sustainable Sweden programme as a whole. Of this, 5,4 billion SEK was specifically destined to support the Local Investment Programmes (LIPs) (Cabinet Bill 1996/97:150, pp. 87 ff.).

\section{'Beating time'? The record of future-oriented ecological modernisation}

The policy statements of leading Social Democrats indicated that they wanted to achieve the ecological modernisation of the 'People's Home' through consensus. The view of the economyecology relationship as a positive-sum game was clearly meant to imply that the road to sustainability is one where present generations would gain as much as those of the future. What, then, is the record so far of the LIPs in terms of autonomy and sustainability?

The political centrality attributed by the Cabinet to the Sustainability Investment Programme is clearly shown in the implementation process. Contrary to usual procedures of distributing grants through formally independent agencies, the Cabinet formed a Special Unit within the Environment Ministry for this purpose. The statute regulating the process and establishing the criteria for grants affords wide leeway and discretion to this Unit 
(SFS 1998:23). Local governments send 'notifications of interest', outlining investment ideas. From these, the Special Unit selects a number of local governments for 'dialogue', during which the investment ideas are further developed. After receiving the final applications, the Special Unit scrutinises them, and may then seek counsel from relevant national agencies and the Regional Administrations. Early assessments of the process pointed to several problems. The criteria for decisions on grants were not clear and transparent. Agency experts were not consulted to an extent that would guarantee the cost-effectiveness of supported investments in relation to environmental objectives (Standing Committee on Housing 1998/99, pp. 25 ff; see Auditors of Parliament 1998/99:97). A survey to the municipal Local Agenda co-ordinators at the end of 1998 revealed that LIPs were seldom anchored within the Local Agenda 21 processes and the sustainability ideas developed in discussions among citizen groups and local politicians and administrators. The indication was rather that administrative and business elites within the municipalities dusted off old pet projects (Brundin and Eckerberg 1999).

The 'consensus' was thus very much one promoted by the activities and views of the Environment Ministry's special unit. This in turn implies that the autonomy of present local citizens expressed, e.g., in Local Agenda 21 plans - was somewhat compromised. But was not this in their long-term interest, as the programme promoted sustainability and thus autonomy for future generations? Under the statute, municipalities applying for LIP grants were required to describe how the proposed measures might stimulate the development of new technology (italics mine). The statute 'demands' that grants to 'sustainability' investments by industry or business must promote such development (SFS 1998:23). However, the technology-driving grants were never more than a tiny part of the whole programme (see Auditors of Parliament 1998/99:87). Even with a very generous interpretation of 'new' technology, only about one (1) per cent of the 2.3 billion SEK granted in the first year were of this kind (Kågesson and Lidmark 1998).

Against this background, it only seems logical that the Swedish government notified the EU of changes in the 1998 statute to the effect that the technology-development conditions for grants to competitive industries and firms is withdrawn from autumn 
1999. Furthermore, Internet information to applicants emphasises that LIP grants are different from other state grants. There is 'no technology driving conditionality, i.e., the Cabinet does not point out which technological solutions should be supported. Instead, the ecological and employment effects are in focus'. The Ecocycle Billion, explicitly designed to stimulate development of technologies for ecologically sustainable development, was taken out of the state budget in April 1999. Only one-fifth was ever used for project grants, and only a few of the supported projects were technology-driving (National Audit Office 1999a:passim. See www.hallbarasverige.gov.se as of June 1999). With the basic element of the ecological modernisation strategy withdrawn, the Prime Minister's vision of the LIP programme as a promoter of green technology and new 'niches' of sustainable growth for Swedish industry thus in effect came to nought.

But could not the programme have employment and environmental effects that would in the longer term justify the Social-Democratic strategy of ecological modernisation? According to the latest available official figures, 141 municipalities (just under half of Sweden's 289 local governments) were granted a total of SEK 5.6 billion to LIPs up to the autumn of 2001. Out of the total investments of SEK 21,5 billion, directly environment-related investments totalled SEK 17 billion. The employment impact estimated by the municipalities comes to about 15,600 'green jobs' up to 2002. There are, however, only about 1,800 permanent new jobs created through LIPs (Government Communication 2000/01:38, p. 24; see http://miljo.regeringen.se/M-dep_fragor/hallbar utveckling/LIP). As for environmental effects of the LIPs, the only base for judgement comes from the estimates made in the municipal application for grants. The funds invested up to 2001 'are expected' to produce the following results:

- Energy consumption down by 2.1 TWh per year.

- Fossil fuels equivalent to 2.3 TWh per year replaced by renewable energy sources.

- Carbon dioxide emissions down by 1.57 million tonnes or 2.8 per cent of all Sweden's emissions.

- Nutrient and phosphorous discharges down by 2 and 4 per cent respectively of the current discharges into water. 
- The amount of waste going to landfill down by 500,000 tonnes, which is the equivalent of 10 per cent of present volumes (Cabinet Communication 2000/01:38, p. 58 f.).

In their assessment of the first two programme years, the Auditors of Parliament stated that meaningful judgements on environmental effects could only be made relative to such quantified objectives that existed before the establishment of National Environmental Objectives and subsequent interim targets (see above, pp. 65-8). For the seven comparisons thus possible, the measures resulting from LIPs granted state support in 1998 contributed only infinitesimally to the actual achievement of these quantified objectives. The Auditors could not judge the LIPs' cost effectiveness, since the Environment Ministry's database did not classify the grants according to estimated environmental effects. Seen from the sustainability perspective, the Auditors' conclusion on the LIPs' contribution to 'A Sustainable Sweden' is worth quoting. The Auditors found it

questionable whether the Cabinet - by using other policy instruments - can stimulate activities that make sure the other 95 per cent of the effects necessary for goal achievement will actually materialise. (Auditors of Parliament 1998/99:97)

\section{Ecological self-binding in Sweden: up or down with the ecocycle?}

\section{'Saving' time: are physical planning and ecocycle adaptation closing in on the future?}

Temporally rational ecological governance means that societal and economic processes are made compatible with underlying, and ultimately binding, ecological and natural resource cycles. The precautionary principle demands that decision-makers at all levels avoid actions that may have irreversible effects on these cycles. But what is irreversible is surrounded by great uncertainty, and may not be discovered until way into the future. The precautionary principle thus forces decision-makers to play it safe by constraining present action through 'self-binding' measures. For such binding to count as temporally rational ecological governance, we defined three constitutive elements: (1) defined target 
dates when specific sustainability objectives are to be achieved, (2) clearly outlined processes of monitoring and evaluation of actual goal achievement, and (3) democratic procedures for decision-making and implementation, regardless of the self-binding strategies used.

Four major Swedish strategies of constraining present action in favour of future sustainability and autonomy have been studied, i.e., physical planning and management by objectives, eco-cycle adaptation, and resource efficiency.

Physical planning exhibits a peculiar relationship to temporally rational ecological governance. The time frames of present physical planning provide a temporal context for environmental and resource management, but do not in and of themselves define targets or dates of their achievement. Defined from political and economic rather than natural cycles, the temporal frames of planning differ among sectors. The problems with physical planning as a means of binding us now for future sustainable development also come out clearly in the quite limited and indecisive role of Environmental Impact Assessments. Physical planning processes have proven unable to block certain large-scale developments with possibly irreversible environmental and resource consequences, with the Hallandsås railroad tunnel as a case in point (see below, pp. 109-11). In terms of autonomy, present planning procedures exhibit a gap between formal and real opportunities for public participation and influence. To what extent resource and environmental considerations emanating from public involvement actually find their way into local master plans is presently unknown.

Having said this, one should however not forget that Sweden's national physical planning has been instrumental in 'preserving' time by defining and defending areas and specific resources of 'national interest'. Almost one quarter of Sweden's area is under such constraints that activities detrimental to sustainable development and environmental quality cannot take place there. The regional Strategic Environmental Guidelines (STRAMs) are a major source of identification and prevention of such areas. Finally, the future linking of all sectoral planning to the 15 National Environmental Objectives and their interim targets, indicates a longer time perspective and a more co-ordinated process. This linkage holds the promise of making the planning 
process more binding on resource-related decision, and thus more instrumental to sustainability.

The eco-cycle adaptation strategy is essentially one of 'saving' time and resources for the future. An increased recycling and reuse of materials and products now leads to lower pressure on the resource base and environmental quality in the future. A clear streak of autonomy is visible. The most remarkable progress has been made in fields where individuals - as consumers and as citizens - have access to markets as well as infrastructural arrangements aimed at easing individual choice of this strategy. Packaging materials, newspapers, as well as glass, aluminium and PET beverage containers are examples of recycling and reuse where achievements are even ahead of projected targets. In terms of sustainability, the fully eco-cycle adapted society is a long way off. Comprehensive infrastructural socio-economic processes such as those of sewage and transportation - will not be adapted for some time to come, because of the 'lock in' effects of present technologies.

What is important to note, however, is that eco-cycle adaptation has become a constituent part of Sweden's environmental and resource policy. Decisions are taken, and moves are made to push further with this strategy. Regulations of material cycles in key industrial and other branches, and explicit timetables for the recyclability/reusability/upgradeability of several products and materials are projected to take effect over the first decade of this millennium.

\section{'Beating time': does ecological modernisation have a future?}

In essence, ecological modernisation holds the promise of 'beating' time. By making energy and resource use more and more efficient, the intergenerational conflict can be avoided (for a glowing Swedish 'homage', see Edman 1998). Efficiency hikes in line with 'Factor 10' will allow present generations to uphold their living standard but still leave future generations with enough resources to allow for autonomous choices of ways of life. Much of this strategy's credibility thus hinges on the actual effectiveness of programmes launched to stimulate the growth of 'green' and 'lean' technology. While it is too early for final judgements on programmes with a temporal scope of generations, the results of presently available evaluations may give 
indications of where these programmes are heading.

When announcing the ecological modernisation strategy in 1996, the Social Democrats said it would build a future, 'green' People's Home, saving environment and resources for future generations. After a flying start there are, however, strong indications that the programme is turning away from this central idea. The technology-driving element, so central to the strategy, has become subdued in the LIPs. The 'Ecocycle Billion' grants to stimulating new resource- and energy-efficient technologies were even abandoned.

The discretionary decision-making process, with lack of strict criteria, little if any analysis of longer-term strategic effects, seemingly no cost-effectiveness analyses, and an almost programmatic non-involvement of expert authorities, seems to have compromised both the sustainability and autonomy elements of temporally rational ecological governance. The programme of subsidies for long-term conversion of Sweden's energy provision and distribution systems is split between authorities and subprogrammes, and thus is difficult to assess in terms of its contribution to sustainable energy provision. All in all, however, the effects on environmental quality and energy conversion from the 'eco-efficiency' strategy seem quite marginal. The Auditors of Parliament even called for a reconsideration of national environmental quality and resource management objectives should this strategy continue.

The 'efficiency' strategy has had a special impact on autonomy and democracy. The LIP grant programme is characterised by a very high degree of centralised decision-making. Traditional ways of implementing decisions through independent expert authorities have been bypassed (see Lundqvist 2001a). Most of the grants to local investment programmes for sustainable development were decided by just a dozen officers within the Ministry of Environment's special LIP unit. Ideas emanating from municipal Local Agenda 21 processes, and anchored within discussions among local citizens, have not found their way into LIP grant applications to an extent compatible with the criterion of autonomy (see Kågesson and Lidmark 1998; Brundin and Eckerberg 1999).

This leads us to an intricate question: Will ecological modernisation - and the 'efficient use' strategies based on it - really 'beat' 
time by bridging us over to affluence for future generations without detriment to the present? Given the record so far, one is forced to answer in the negative. For the ecological modernisation's 'positive-sum-game' to materialise, more resource-efficient and environment-friendly technologies must develop, and provide new opportunities of socio-economic development also for the present generation. When that element is compromised, as seems to be the case for Sweden, the auspices for autonomy and sustainability held out by ecological modernisers certainly seem clouded.

\section{An idea just in time? The prospects of ecological management by objectives}

Still, temporal aspects are integrated parts of Sweden's environmental and resource policies. Planning regulations, programmes for ecocycle adaptation, and even efficient use strategies do address the longer-term aspects of sustainable development, and are binding - with different strengths - on future decisions. But if there is not enough of 'saving' and 'reserving' time, and if the prospects of 'beating' time are not all that clear, is there really a future for temporally rational ecological governance?

Perhaps the most interesting answer to this question is provided by an idea whose time has just come, i.e., ecological management by objectives (MBO). The three overarching objectives of protection of environmental quality, efficient use of resources, and sustainable ecosystem productivity formulated in 1997, explicitly lifted the perspective to one generation from now to around 2020-25. With the 15 National Environmental Objectives and the specification of interim targets, ratified by Parliament in 1999 and 2001 respectively, all societal sectors will have explicit goals and target dates for sustainable resource use and environmental management by the middle of the first decade of the third millennium.

The reader may argue that this is just some rattling at the fences, and not a binding pledge to attack problems of sustainable development. Admittedly, management by objectives is a loosely structured process in classic political and administrative terms. But the interim targets are there, binding agencies and actors involved in the process of developing sub-goals and targets further down the line. They will most probably come to feel formally, but above all mentally, bound to these objectives and 
targets. Another crucial aspect of the MBO strategy is that the choice of methods of goal achievement is left with the responsible agents and their client groups. The agencies and the politically responsible elites must bring responsible sectoral actors into consensus around the objectives and constructive decisions as to proper measures for goal achievement, something that implies a considerable degree of autonomy in the process.

However, temporally rational ecological governance is not just about how to arrange political institutions to take account of different life cycles and time scales important to the balance of ecosystems. To the aspect of becoming 'green in time' is thus added the aspect of being politically accountable and 'just in time'. A most interesting aspect of the $\mathrm{MBO}$ strategy is its entrenchment in central bureaucracy. In effect, present bureaucrats function as 'ombudsmen' for future generations. If the subgoals and targets come to reflect judgements of administrative feasibility as much as considerations of levels necessary for sustainable development, this may affect the autonomy of future generations. It should, however, be noted that an elaborate structure of political, and thus open, review of progress towards goals and targets is envisaged with annual reports to Parliament, and a broad State of the Environment report every mandate period. Together with the explicit linking of the MBO strategy to a supportive context of monitoring, evaluation, and new statistical accounts, this means that the development towards goals and targets can be closely scrutinised and the adequacy of goals and targets challenged by the interested citizen. 